\title{
Chapter 11 \\ Cosmopolitanism in US Sanctuary Cities: Dreamers Claiming Urban Citizenship
}

\author{
Catherine Lejeune
}

\subsection{Introduction}

"The rise of sanctuary cities signals the ability of cities to contest the exclusionary nature of national citizenship and redefine the contours of citizenship in a more inclusive manner" (Lambert and Swerts 2019, 91). I will use this statement as a starting point to discussing contemporary US sanctuary policies and practices, and their relationship to the undocumented population in cities, with a focus on migrant youth activism.

Revisiting sanctuary cities seems appropriate as references to the US designation are made more and more frequently at a moment when Western countries face large arrivals of populations seeking refuge, asylum or an immigration status. Since 2015 the scholarly literature on the "migration crisis" in Europe has consistently referred to sanctuary as a possible model for cities willing to host and accommodate the needs of refugees, asylum seekers and undocumented migrants. The emergence of sanctuary policies in Germany, Spain, the United Kingdom, Canada, Chile and Australia indicates that the concept has been used, adapted, and refashioned. Meanwhile, the city-sanctuary movement is expanding in the US with cities renewing their status and others seeking to obtain it in order to counter the Trump administration, making it all the more necessary to carry the investigation further.

Sanctuary is far from being a clear-cut concept; it takes on different forms and concerns different groups depending on socio-spatial contexts around the world. Yet what unifies city policies worldwide is that they have all emerged in the same context of harsh national and international treatment of migrants and asylum seekers (Dauvergne 2016; Squire and Bagelman 2012). The phenomenon is not new and has already received much attention from scholars, NGOs, political actors, and the civil society: the increasing illegalization of migrants and refugees through restrictive

\author{
C. Lejeune $(\triangle)$ \\ LARCA, Université de Paris, Paris, France
}

(C) The Author(s) 2021

C. Lejeune et al. (eds.), Migration, Urbanity and Cosmopolitanism in a

Globalized World, IMISCOE Research Series,

https://doi.org/10.1007/978-3-030-67365-9_11 
national migration policies in Western countries since the 1990s has prompted cities to offer sanctuary to vulnerable populations (Bauder 2016).

In this chapter, I do not intend to examine how both the term and the concept travel. Compelling comparative studies by urban geographers (Bauder 2017; Lippert and Rehaag 2013) illustrate the need for a detour into different national contexts to make sense of sanctuary. Drawing on their theoretical and empirical work and on the sizeable body of literature in the field (Bauder 2016, 2017; Bauder and Gonzales 2018; Bauder and Darling 2019; Darling 2017; Ridgley 2008; Lippert and Rehaag 2013; Varsanyi 2006; Lasch et al. 2018), I intend to unpack the concept to demonstrate how US sanctuary cities produce new forms of urban citizenship to undocumented migrants, thus contributing to the debate on sanctuary and the need to conceptualize it. As I examine some of these policies and practices, I will introduce the concept of cosmopolitanism to discuss migrants' acts of citizenship.

\subsection{Sanctuary Cities Foster Urban Citizenship}

What are sanctuary cities offering that has garnered so much attention? In European countries, in the UK for example, sanctuary supports a culture of welcoming asylum seekers and refugees based on "ideals of responsibility and hospitality" (Darling 2010, 2017; Squire 2011). In North America, sanctuary tends to focus on municipal policing practices aiming at protecting illegalized/undocumented migrants, and one of its rationales is to promote diversity and inclusiveness (Lasch et al. 2018). ${ }^{1}$ Unsurprisingly, sanctuary initiatives fuel the animosity of the current US president who has long used a nationalistic rhetoric that further criminalizes immigration. ${ }^{2}$

How does a city receive sanctuary status? There are different types of procedures. One consists in implementing policies for public safety and immigration enforcement; another, in creating municipal identification cards. Such policies may be enacted in small or large cities, they may vary in form and content, some being more proactive than others (and in a few cases, they may not even be labeled as part of a strategy to make the city a "sanctuary"). Typically, cities enact policies of noncooperation with the federal agency in charge of immigration enforcement (ICE). Such policies, referred to as DADTs - Don't ask, Don't tell - enable all residents to access city services without revealing their legal status.

Scholars agree that legislating for access to municipal services regardless of status and protecting residents by refusing to cooperate with immigration authorities constitutes a form of urban citizenship (Ridgley 2008; Darling 2017). But this form of citizenship does not necessarily come with inscribed rights for unauthorized

\footnotetext{
${ }^{1}$ Bauder refers to migrants without immigration status as "illegalized," focusing on the responsibility of national authorities in the production of illegalization. The scholarly literature in the field often uses the term "undocumented." I favor this designation and use it throughout the chapter.

${ }^{2}$ The criminalization of US migration dates back to the 1990s when several restrictive and punitive laws were passed in Congress.
} 
migrants (Varsanyi 2006). Rather, the ordinances enacted by cities can be seen as "means to maintain informality."3

Because they are both protective and inclusive, sanctuary initiatives challenge the criminalization of migrants, somehow disrupting the state's monopoly over migration policy. Undocumented migrants can still be subjected to deportation orders, and the number of deportations has continued to rise in the Trump era, even in sanctuary cities, which means they do not cancel illegality per se; however, by facilitating migrants' everyday lives, they are supporting alternative visions of citizenship.

City identification cards are a good illustration of how sanctuary policies and practices circumvent the national prerogative to issue membership status by, as Lebuhn puts it, "inventing" local membership (quoted in Bauder and Gonzalez 2018). Global cities like New York, as well as smaller cities like New Haven, Connecticut, have issued local identification cards that can be obtained through proving residency. ${ }^{4}$ These city IDs facilitate opening bank accounts, applying for city programs, enrolling in local schools, etc. While they are designed for all city residents, identification cards clearly address the needs of the undocumented living within the city area.

By affirming their commitment to accommodating migrants who do not possess full federal status, such initiatives are challenging. The power to confer legal citizenship remains in the hands of the federal government, but citizenship encompasses factors that go far beyond legal status, including rights, inclusion and political participation (Torres 2017).

Such programs explicitly put forward the inclusionary impact on all city residents, whether migrants or not. The case of the New York city ID program (IDNYC), introduced by Mayor Bill de Blasio in 2014, is interesting for that matter. With its campaign including language access programs, a city council allocation towards DACA outreach and the municipal identification program, the Mayor's Office of Immigrant Affairs intends to facilitate inclusion for undocumented residents. While it may be argued that the weakness of the campaign lies in its lack of leverage to legalize this population, it is nevertheless admitted that the campaign has developed a relatively stable social life for undocumented residents "showing evidence of certain spaces of inclusion outside of formal national citizenship" (Ruszczyk 2018, 6).

Besides, a 2016 survey conducted by the city showed that many non-migrants have adopted the ID card in support of the program, expressing a desire to show solidarity with other residents. ${ }^{5}$ This can be explained in part by the traditional

\footnotetext{
${ }^{3}$ See Darling (2017) for a detailed discussion of informality and presence in the city.

${ }^{4}$ Municipal ID cards for undocumented immigrants were first created in San Francisco in 2009; the measure was later adopted in NYC and Los Angeles, among other cities.

${ }^{5}$ The New York Mayors' Office for Immigrant Affairs publicizes its IDNYC as "the largest municipal ID program in the country." Its objective is to make it "as effective and inclusive as possible." IDNYC benefits every New York City community, including the most vulnerable communities, such as undocumented immigrants, the homeless, youth, the elderly, formerly incarcerated individuals and others who have difficulty obtaining a government-issued ID" (see https://www1.nyc.
} 
public support of immigrants in New York city. It can also be explained by the message of generalized urban inclusion contained in the message sent by resident cards programs.

In her study of sanctuary as a process in the US (2019), Serin Houston demonstrates how the motivations of sanctuary in San Francisco and Richmond, California - based on assumptions that reduced crime, greater access to services and resources and the positive benefits of legitimate personal identification are good for all residents - show such policies are not only about noncitizens. The process does not just include the benefits of a municipal ID, she explains. It also reveals how sanctuary "exceeds a mere locality designation," positively influencing everyday encounters for and between residents.

Scholars agree to say that sanctuary is transforming urban society and claim that sanctuary initiatives are changing the discourse of migration and belonging, by reimagining the city as an inclusive space. In this way, sanctuary cities are reframing the meaning of belonging and membership at the urban, rather than national, scale. In the UK, sanctuary cities do not focus so much on policing or non-cooperation with national authorities but they do send an important symbolic message concerning the inclusion of refugees in particular (Bauder 2018). Whether they are more action-oriented, as in the US, or more discourse-oriented, as in the UK, these cities change the imagination of the city as a place of welcome and in so doing, they shape the manner in which residents interact with each other (Darling 2010; Darling and Squire 2013; Squire and Bagelman 2012). ${ }^{6}$

Sanctuary policies do not only promote the social inclusion of unauthorized migrants. They also increase the opportunities of daily interactions and foster urban sociabilities as the following discussion on migrant activism highlights it.

\subsection{Undocumented Migrant Activism}

Since the turn of the century, urban theorists have consistently presented cities as pivotal sites with an insurgent potential, offering possibilities for protest. Geographers in particular have come to understand the city as a space where the substance of citizenship is given form, as mentioned earlier (Ridgley 2008; Sassen 2005; Isin 2002; Robinson 2002). Therefore cities, with their "activist" potential, are places where migrants engage in protest practices of citizenship. Some scholars

gov/site/immigrants/index.page). IDNYC can be presented as proof of identification for interaction with the police and is an accepted form of ID for opening a bank account at select financial institutions. It is currently held by 1.3 million people ( 1 in 8 of the population) and has been taken up by about half a million undocumented migrants. See European Council Policy Brief, Urban Citizenship and Undocumented Migration, February 2019, and www1.nyc.gov/site/idnyc/about/ about.page

${ }^{6}$ See Bauder (2018) for a detailed analysis of the aspects that define sanctuary in the US, Canada and the UK. 
have investigated the relation between undocumented activism and the city. Swerts's study in particular illustrates how undocumented migrants rely on urban space for their struggles over citizenship (Swerts 2017). Sanctuary cities are key as they produce safe spaces where performing acts of protest (against exclusion from the national) and acts of appropriation (of and through urban space) can be deployed in a relatively open way. They are trustworthy spaces where the in-betweenness of migrants can be best observed and understood.

Let us consider the 1.5 generation in the US - a term that refers to foreign-born immigrant youths who came to the US with their parents as children. Though they were raised and educated in the US, they are subjected on a daily basis, along with other non-status migrants, to vulnerability and fear of deportation. As such, they illustrate the ultimate case of in-betweenness.

The absence of formal status makes them "illegal" under the law and at risk of deportation in the same way as the overall unauthorized population of the US. At the same time, because of their education and long-time US residence, they constitute a specific category of immigrants. In the last 10-15 years, scholars have growingly studied this estimated population of about 800,000 youths nationwide, focusing on the existing contradiction between their education, which the law authorizes, and their transition to adulthood when they become aware of the impossibility to be formally included in US society because they cannot be further educated or work legally (Gonzales 2016; Nicholls 2013). ${ }^{7}$

Conferring legal status on undocumented migrant youth brought to the U.S. as children - a group referred to as DREAMers - has been the subject of legislation in the US Congress since 2001 but has failed to reach a consensus. In 2012 the Obama administration launched the Deferred Action for Childhood Arrivals initiative (DACA) to provide temporary relief from deportation and work authorizations to those who qualified under the program, with the following requirements: having been in the US since 2007, being under the age of 16 at the time of arrival and under the age of 31 as of 2012; they also had to be enrolled in school and have a high school diploma or equivalent. ${ }^{8}$

The initiative has embroiled all three branches of US government since its creation, with each branch hoping the other would bail it out of a politically sensitive issue like how to address the fate of a population widely seen as sympathetic across the partisan divide. DACA was in effect until September 2017, when the Trump administration announced its intention to terminate the program and end work authorization and protection from deportation for DACA recipients. Since then, several federal courts have blocked the administration, somehow keeping the program alive for people who currently have or have held DACA status without being

\footnotetext{
${ }^{7}$ They have the right to be schooled from kindergarten through grade 12, the last year of high school. This right was enacted by the Supreme Court ruling Plyler v. Doe 457 U.S. 202 (1982).

${ }^{8}$ This was undertaken through an executive action: presidents can legally take such decisions but they rarely do so as in the US, immigration policy is typically the responsibility of Congress. Barack Obama took this action in the absence of congressional action.
} 
effective in completely preventing deportations orders. This is where the situation stands at the time of writing this essay.

President Trump has threatened to strip federal funding from sanctuary jurisdictions if they do not share citizenship or immigration status information with the federal government. Some cities capitulate; others, significantly, resist and challenge the federal action in court. The city (and county) of San Francisco did just that: they sued the federal government and won the case. The US Circuit Court of Appeals struck down president Trump's executive order of 2017 to end federal grant funding to sanctuary cities. ${ }^{9}$ The lawsuit challenged the order on the claims that it was unconstitutional because only Congress can impose conditions for federal grant appropriations. ${ }^{10}$ The San Francisco $v$. Trump injunction was a notable victory for cities (Kwon and Roy 2018). This lawsuit is one of many against the Trump administration concerning executive orders against sanctuaries. Interestingly, so far courts have ruled in favor of cities.

Not only have cities renewed their commitment to sanctuary in response to the measures outlined in Trump's executive action but, as a sign of protest against his antagonism and anti-immigrant rhetoric, they tend to make more explicit statements about the safe spaces they provide for the vulnerable, be they refugees or non-status migrants.

DREAMers have used those safe spaces to engage in migrant activism as the DACA program results largely from their struggles. Not all of it occurs in cities, and the rebirth of sanctuaries since the presidential election has been observed in churches, campuses, counties, and even at state level. But undocumented activism has been decisive in cities, particularly in sanctuary cities where migrant youth have been able to deploy their actions in an environment that is not hostile. Starting in 2010, they learned how to identify public arenas (online and on campuses, for instance) where they could build their cases and express their claims, "plan and undertake high risk protests, and lobby public officials to support bills recognizing their rights and the rights of other undocumented immigrants in the country" (Nicholls 2013, 8).

\footnotetext{
${ }^{9}$ Executive Order 13768 (25 January 2017) is entitled "Enhancing Public Safety in the Interior of the US."

${ }^{10}$ The opinion summary of court decision N17-17478 (2018):

Under the principle of Separation of Powers and in consideration of the Spending Clause, which vests exclusive power to Congress to impose conditions on federal grants, the Executive Branch may not refuse to disperse federal grants to sanctuary cities and counties without congressional authorization. President Trump issued Executive Order 13,768 (Enhancing Public Safety in the Interior of the United States") with the purpose of directing executive departments and agencies to employ all lawful means to enforce immigration laws. The Executive Order's primary concern was sanctuary jurisdictions, which the President viewed as willfully violating Federal law in an attempt to shield aliens from removal from the country. (2 August 2018, at JURIST, http://jurist.org)
} 
This advocacy emerged from a loose network of undocumented students who chose to use their personal stories to attract attention. The DREAMer narrative relied on the figure of the undocumented youth portrayed as an integrated person (who grew up in the US, speaks fluent English and feels American), innocent (brought to the country as a child) and hard-working as much as successful - hence, the very embodiment of a "deserving" student. Their strategy was frequently criticized for its exclusionary effects in the first years of the movement as it implied that other immigrants were not as deserving as they were. ${ }^{11}$ The movement started to fracture as students stopped using arguments. Irreconcilable tensions became salient with the intersectionality of those who wanted to include gender and racial identities in their stories and the refusal of others to blame their parents for bringing them to the US. Nonetheless, the movement was successful in positioning the personal stories of undocumented childhood arrivals in order to influence policymaking (see Carney et al. 2017).

The transformation of the movement since 2011 has been analyzed as "contentious politics" that challenges the previous focus on students (immigration reform, citizenship status); it also has the potential to emerge as a counter-hegemonic project in that it rejects discourses that reproduce the criminalization of unauthorized migrants. In recent years, the movement has been more inclusive of different subjectivities within undocumented communities (queer, uneducated people or ones with a criminal record), thus redefining notions of citizenship. The focus shifted back to a more explicit fight against criminalisation and no longer in the direction of "legislation that would never pass." As such, its participants can be seen as activist citizens - to quote Engin Isin - constituting themselves as citizens regardless of status (Isin and Nielsen 2008).

The strategy used by undocumented youths as the movement transformed is known as "Shout is out" or "Coming out of the shadows." They would hold meetings and organize rallies where they normalized the act of stating out loud that they were undocumented. The practice started to empower them while portraying the diversity of the undocumented population at large. It also changed their status from a private matter to a public issue. They made the responsibility for their situation, which some initially felt was individual, a social question, by appearing as undocumented in public transforming the internalized shame attached to their illegalized status and their fear of being deported into some sort of "defiant pride": not only naming their status but creating a political subjectivity (Butler 1997). The experiences of these immigrant youth were articulated in a common discourse that associated being undocumented with being also unafraid and unapologetic - a way of politicizing their experiences. The individual story-telling that unfolded during those "Coming out of the shadows" events allowed for a much broader and inclusive narrative, introducing an open communicative method.

\footnotetext{
${ }^{11}$ Noam Chomsky, among others, voiced his critique in Undocumented: How Immigration Became Illegal (Boson: Beacon Press, 2014).
} 


\subsubsection{On Activism in High School}

Schools, typically, are supposed to be safe spaces. Recent studies based on theory and ethnographic observation, investigate undocumented activism (Kuge 2019; Schwiertz 2016; Gonzales 2016; Swerts 2017) but more work needs to be done across the disciplines. Empirical studies would help scholars make sense of inbetween statuses, and schools are perfect places to carry them out.

I was able to attend a few sessions organized by a DREAMers' team in a New York City public school in 2013 and again in 2014, at a time when expectations were high and activism was invigorated by the recently-passed DACA measure.

I first met 16-year-old Naflan in a rally on DACA organized by the New York Immigration Coalition, a prominent advocacy group in New York City. He suggested I attended the meetings of the "DREAMers Club" at his school (Curtis High School, Staten Island). I attended several gatherings after that with the help of the school advisor. During the meetings, I was able to observe the interactions between students (aged from 14 to 17) as they openly spoke about their status with the group. While the majority was undocumented, a minority of students was not. Some were in the process of applying for DACA; a few had already qualified for DACA status but insisted on sharing their experience and being with the group. Others remained mostly silent but were present at each of the following sessions.

As they shared their experience of undocumentation with me, their advisor and the other students, I was struck by the diversity of the participants' countries of origin, very much a reflection of the heterogeneous foreign-born population in some parts of the city. I was amazed at how little attention was paid to where they were from, and how much to why they were here. The focus was on telling their story and deciding which action should be taken next: they were activists in the making. Their solid involvement in the movement, sustained over a period of several months, gave them a sense of purpose, a way to reach out and help others with the practicalities of applying for DACA status. Working as a local team supported by several of their teachers gave them a sense of belonging, a shared identity through humanistic dialogue while fighting against the criminalization which had relegated them (and their parents) to an outsider status. "Our common ground is: "not having status," one student said. "It is not a matter of ethnicity, it's about papers. We all don't have papers." He highlighted the commonalities that drew them to one another and which generated the collective will to act.

Emotion was part of the experience. Sociologist Roberto Gonzales describes the shock that many students experience when they "discover" their undocumented status between the age of 16 and 18 as they transition from public education into adulthood, which for them brings about a whole host of limitations, like not being able to apply for a driver's licence for lack of documentation, not being eligible for any financial aid for college, indeed no possibility to attend college at all. In one of the meetings I sat at, Naflan used the following words to describe how he learnt about his immigration status through his father: "My dad just told me one day: 'we're not supposed to be here.' I wanted to prove him wrong." 
As they voiced their frustration and pain publicly, a relation of trust grew among the students at the school, and I was able to observe that the repeated interactions were consolidated into deeper relations after a few weeks. Obviously, they had been able to build strategies that helped them go beyond their differences (whether social, cultural, ethnic or religious). In the safe and supportive space of the school, their shared vision of how to act fostered commonalities and developed ways of being together.

In 2017, a collective of scholars wrote a text in the form of a manifesto advocating for a global sanctuary movement. They argue that sanctuary not only gives undocumented migrants a sense of belonging to the city where they reside because what matters is where they live and not where they were born, but it also impacts their relationships with others. In fact, sanctuary fosters relationships between people, and between people and institutions (Carney et al. 2017). This is a collaborative practice, one that has the capacity to produce connections between individuals and institutions committed to the same values.

For Isin, the struggles led by undocumented migrants are typically acts of citizenship. It is common practice among undocumented youth who use the protective environment of schools to share their story (Gonzales 2016; Swerts 2017); this is also what I witnessed during the high school meetings I attended, which perfectly illustrated the principle of "shout it out" based on the "coming out of the shadows" strategy. ${ }^{12}$ Such acts, Swerts justly notes, are highly transformative events for undocumented youth that represent a first step in the formation of their political subjectivities. His comparative study of activism in Brussels and Chicago stresses the important role of schools and universities in offering a supportive environment for the initial self-organization of undocumented youth.

\subsection{Concluding Remarks: Migrant Acts and Cosmopolitanism}

Cosmopolitanism, geographer Barney Warf notes, "seeks to overcome the dichotomous fixation on 'we' and 'them', citizens and immigrants, the local and the global. In this view, there is no such thing as an illegal immigrant, for no 'human being is illegal'" (Warf 2015, 932). ${ }^{13}$ The divide Warf refers to explains why, I believe, the cosmopolitan approach is absent from the scholarly literature on migration in the US, unlike in France for example. ${ }^{14}$ In the United States, the image of the migrant

\footnotetext{
${ }^{12}$ This was inspired by Harvey Milk and the Gay Rights Movement's "coming out" strategy (see Swerts 2017).

${ }^{13}$ Warf here makes a reference to the Noone Is Ilegal (NOII) migrant justice group in Toronto, which has launched a solidarity city network. NOII calls for the regularization of all non-status persons.

${ }^{14}$ Other English-speaking countries use the cosmopolitan approach in migration studies, most notably Australia.
} 
has historically been constructed as that of the "other". The undocumented migrant, in particular, has long been categorized by law as the illegal alien seen as a persistent threat to US society. ${ }^{15}$

Unsurprisingly, to adopt the language of tolerance and empathy for those who have been consistently portrayed as negatively different throughout history and to celebrate the hyper diversity of cities in a country with such a "dichotomous fixation" is not an easy task, but it has been undertaken.

The now classic study by Lamont and Aksartova (2002) which documents the cosmopolitan imagination (and strategies) used by "ordinary" people to counteract racism demonstrates that the bridging of boundaries does exist in the US. Elijah Anderson's Cosmopolitan Canopy (2012) is another fine example of ethnographic studies examining moments of conviviality shared between people of different backgrounds at a Philadelphia market (a segregated city where social mixing is otherwise unlikely).

Empirical research using cosmopolitan tropes is needed as it can possibly reveal more about the way people informally interact with others in sanctuary cities; it can also show to what extent acts of citizenship performed by undocumented migrants are, indeed, cosmopolitan acts. An emerging radical literature in the field of political theory advocates the migrant as the key figure of cosmopolitanism "from below" (Nail 2015; Caraus 2018; Sager 2018). Migrants' acts of citizenship are inherently cosmopolitan, Caraus argues, because they challenge the prerogatives of the nation state and they imagine new ways of being in the world.

\section{References}

Bauder, H. (2016). Possibilities of urban belonging. Antipode, 48(2), 252-271.

Bauder, H. (2017). Sanctuary cities: Policies and practices in international perspectives. International Organization for Migration, 55(2), 174-187.

Bauder, H., \& Darling, J. (2019). Rescaling migration, citizenship and rights. Manchester: Manchester University Press.

Bauder, H., \& Gonzalez, D. (2018). Municipal responses to ‘illegality': Urban sanctuary across national contexts. Social Inclusion, 6(1), 124-134.

Butler, J. (1997). The psychic life of power. Stanford: Stanford University Press.

Caraus, T. (2018). Migrant protests as acts of cosmopolitan citizenship. Citizenship Studies, 22(8), 791-809.

Carney, M., Gomez, R., Mitchell, K., \& Vannini, S. (2017). Sanctuary planet: A global sanctuary movement for the time of trump. Society \& Space. Online at https://www.societyandspace.org/ articles/sanctuary-planet-a-global-sanctuary-movement-for-the-time-of-trump

Darling, J. (2010). A city of sanctuary: The relational re-imagining of Sheffield's asylum politics. Transactions of the Institute of British Geographers, 35(1), 125-140.

Darling, J. (2017). Forced migration and the city: Irregularity, informality, and the politics of presence. Progress in Human Geography, 41(2), 178-198.

\footnotetext{
${ }^{15}$ See the work of historian Mae Ngai (2004) for a study of the production of migrant illegality by US law.
} 
Darling, J., \& Squire, V. (2013). Everyday enactments of sanctuary: The UK City of sanctuary movement. In R. Lippert \& S. Rehaag (Eds.), Sanctuary practices in international perspectives (pp. 191-204). Routledge: Abingdon.

Dauvergne, C. (2016). The new politics of immigration and the end of settler societies. Cambridge: Cambridge University Press.

Gonzales, R. (2016). Lives in limbo: Undocumented and coming of age in America. Berkeley/Los Angeles: University of California Press.

Houston, S. (2019). Conceptualizing sanctuary as a process in the United States. Geographical Review, 109(4), 562-579.

Isin, E., \& Nielsen, G. (2008). Introduction. In E. Isin \& G. Nielsen (Eds.), Acts of citizenship (pp. 1-12). Chicago: University of Chicago Press.

Isin, E. (2002). Being political: Genealogies of citizenship. Minneapolis: University of Minnesota Press.

Kuge, J. (2019). Uncovering sanctuary cities. In J. Darling \& H. Bauder (Eds.), Sanctuary cities and urban struggles. Manchester: Manchester University Press. Chapter 2 in Ebook.

Kwon, C., \& Roy, M.( 2018, January 20). Local action, national impact: Standing up for sanctuary cities. Yale Law Journal Forum. At https://www.yalelawjournal.org/forum/ local-action-national-impact

Lambert, S., \& Swerts, T. (2019). 'From sanctuary to welcoming cities': Negotiating the social inclusion of undocumented migrants in Liège, Belgium. Social Inclusion, 7(4), 90-99.

Lamont, M., \& Aksartova, S. (2002). Ordinary cosmopolitanisms. Theory, Culture and Society, 19(4), 1-25.

Lasch, C., Chan, R., Eagly, I., Haynes, D., Lai, A., McCormick, E., \& Stumpf, J. (2018). Understanding 'sanctuary cities'. Boston College Law Review, 59, 1703.

Lippert, R., \& Rehaag, S. (2013). Sanctuary practices in international perspectives: Migration, citizenship and social movements. London: Routledge.

Nail, T. (2015). Migrant cosmopolitanism. Public Affairs Quarterly, 29(2), 187-199.

Ngai, M. (2004). Impossible subjects. Princeton: Princeton University Press.

Nicholls, W. (2013). Making undocumented immigrants into legitimate political subjects: A comparison of France and the United States. Theory, Culture and Society, 30(3), 82-107.

Ridgley, J. (2008). Cities of refuge: Immigration enforcement, police, and the insurgent genealogies of citizenship in U.S. sanctuary cities. Urban Geography, 29(1), 53-77.

Robinson, J. (2002). Global and world cities: A view from off the map. International Journal of Urban and Regional Research, 26(3), 531-554.

Ruszczyk, S. (2018). Local governance of immigrant incorporation: How city-based organizational fields shape the cases of undocumented youth in New York City and Paris. Comparative Migration Studies, 6.1, 32. Online at https://www.ncbi.nlm.nih.gov/pmc/articles/ PMC6223885/.

Sager, A. (2018). Reclaiming cosmopolitanism through migrant protests. In T. Caraus \& E. Paris (Eds.), Migration, protest movements and the politics of resistance (Vol. 171, p. 185). London: Routledge.

Sassen, S. (2005). The repositioning of citizenship and alienage: Emergent subjects and spaces for politics. Globalizations, 2(1), 79-94.

Schwiertz, H. (2016). Transformations of the undocumented youth movement and radical egalitarian citizenship. Citizenship Studies, 20(5), 610-628.

Squire, V. (2011). From community cohesion to mobile solidarities: The city of sanctuary network and the strangers into citizens campaign. Political Studies, 59(2), 290-307.

Squire, V., \& Bagelman, J. (2012). Taking not waiting: Space, temporality and politics in the city of sanctuary movement. In P. Nyers \& K. Rygiel (Eds.), Citizenship, migrant activism and the politics of movement (pp. 146-164). London: Routledge.

Swerts, T. (2017). Creating space for citizenship: The liminal politics of undocumented activism. International Journal of Urban and Regional Research, 41(3), 379-395. 
Torres, A. (2017). I am undocumented and a New Yorker': Affirmative city citizenship and New York City's IDNYC program. Fordham Law Review, 86, 335.

Varsanyi, M. (2006). Interrogating 'urban citizenship' vis-à-vis un- documented migration. Citizenship Studies, 10(2), 229-249.

Warf, B. (2015). Global cities, cosmopolitanism and geographies of tolerance. Urban Geography, 36(6), 927-946.

Open Access This chapter is licensed under the terms of the Creative Commons Attribution 4.0 International License (http://creativecommons.org/licenses/by/4.0/), which permits use, sharing, adaptation, distribution and reproduction in any medium or format, as long as you give appropriate credit to the original author(s) and the source, provide a link to the Creative Commons license and indicate if changes were made.

The images or other third party material in this chapter are included in the chapter's Creative Commons license, unless indicated otherwise in a credit line to the material. If material is not included in the chapter's Creative Commons license and your intended use is not permitted by statutory regulation or exceeds the permitted use, you will need to obtain permission directly from the copyright holder. 